they, having the run of all the London hospitals, will be in a much better position to suit you at the same cost. So one more link with the past will have been broken. I cannot do better than sign myself with the old hospital motto,

Feb. 11th, 1894. I am, Sirs, yours truly, "DARE QUAM ACCIPERE."

\section{THE FUNCTION OF THE MEDICAL OFFICER OF HEALTH.}

To the Editors of THE LANCET.

SIRS,-I enclose a letter which the clerk of the Garstang rural sanitary authority has just received from the Local Government Board in reply to a complaint of mine about the conduct of the medical officer of health in visiting and examining my private patients without $m y$ knowledge or consent, or without asking the consent of the patient or his friends. The medical officer of health declined to refer the proceeding to your decision or to that of any medico-ethical association, but claimed compulsory powers to examine all cases under the Public Health Act. The decision is the clearest and most definite the Local Government Board have yet given on the subject, and no doubt you will bring it before your readers and make some observations on it, as there is a good deal of doubt as to the duties of the medical officer of health in such cases.

I am, Sirs, yours truly,

Garstang, Feb. 11th, 1894. J. J. GoRHAM, M. A., M.D.

Local Government Board

Whitehall, S.W., Feb. 2nd, 1894

SIR,-I am directed by the Local Government Board to advert to sour letter of Dec. 28th last with reference to the representations which bave been made by Dr. Gorham of Garstang as to the action of the medical officer of health for the Garstang rural sanitaly district in visitirg certain of his pstients. As regards the general question of the medic diseas 1 om then isease 1 am to state that the Jnfectious Difease (Notification) Act 1859, makes no difierence in those duties, but merely extenus his in cormation as to the existenco of cases of infectous disease. His duties as regards such cases are r rescribed by Article 18 (6) of the Board's urder of March 23rd, 1891, of which a copy is enclosed.

It appears to the Board to be undesirable that the medical officer of health should in general undertake a personal diagnosis of the notified cases in order to test the accuracy of the certificates. In some cases, as where there is reason to doubt the good faith of the certifier or where the disease is one which in itself is or, owing to the attendant circumstances, threatens exceptional danger to the community, it may be desirable that the medical officer should make a personal diagnosis, but it must be remembered that this can only be done with the consent of the patient or those having charge of the patient, and that the medical practitioner in charge of the case should always be communicated with and his cooperation secured if possible.

$$
\text { I am, Sir, your obedient servant, }
$$

Signed) AlFred J. ADRIAN, Assistant Secretary.

J. Noble, Esq. Clerk to the Rural Sanitary Authority

$$
\text { of the Garstang Union. }
$$

\section{"THE CONDITION OF CHRIST'S HOSPITAL." To the Editors of THE LANCET.}

SiRs,-As the note in The Lancers of to-day on the question of the "Condition of Christ's Hospital" evidently arises from a wrong conception of the scheme suggested by the Council of Almoners to the Commissioners of Sewers (for which scheme I am in a great measure responsible), and also suggests that it may be a " tinkering process," may I simply state the following facts: -1 . That the specifications and plans submitted to the Commissioners are for a thorough reconstruction of the entire drainage system with new pipes and fittings throughout, proper manholes, and efficient ventilation of all the drains, as also absolute disconnexion from the street sewers, together with a reconstruction of all the water-closets and their approaches. 2. That the plans and specifications first sent in were subsequently submitted to the opinion of the well-known sanitary expert, Dr. Louis Parkes, lecturer on hygiene at St. George's Hospital. 3. That Dr. L. Parkes suggested certain improvements and wrote an additional report, which has been forwarded to the Commissioners of Sewers, and has given his written opinion to the council of Christ's Hospital that if the works suggested by us, and modified as he desires be carried out they will fully satisfy all the sanitary requirements and also comply with the notice under the Public Health Act served on Christ's Hospital by the Commissioners of Sewers. In my very responsible position here, and with a thorough knowledge of the existing defects in our sanitary system, it is hardly likely that I should give my unqualified approval to any half-measures ; and the readers of THE LAXCET and the public generally may rest satisfied that no " tinkering processes," "by which risks to the bealth and life of the Bluecoat boys would be run," have ever been suggested by-Yours faithfully,

H. ALDER-SMITH, F.R.C.S., M.B.Lond.

Medical Officer to Christ's Hospital since 1870.

Upper Wimpole-street, W., Feb. 10tb, 1894.

* * We are very glad to receive the disclaimer of any intent upon the part of the hospital authorities to sanction halfmeasures, but our note was not intended to contain the reflection that has been seen in it.-ED. $L$.

\section{"EXPERIMENTAL DEGENERATION OF THE PYRAMIDAL TRACT."}

To the Editors of THH LANCET.

SIns, - In reference to the letter from Professor Horsley in the last issue of THE LAANCET, I beg leave to state that when I recommenced the observations to which he refers I was unaware that anyone in Professor Horsley's laboratory or elsewhere had undertaken similar work, or was thinking of so doing. In October last Professor Boyce, on my meeting him at the Physiological Society, asked me whether I was working at the subject in question, and received from me a perfectly open reply about my work; it was at that time, and from Professor Boyce, that I first learned that work of a kindred scope was going on in Professor Horsley's laboratory. My own work had then been in progress several months. I felt surprised that Professor Horsley should not have mentioned the matter to me, but I supposed that he would do so prior to publishing the work. In the middle of the fourth week of January last Professor Boyce paid a visit to my laboratory on a different matter, but while there he told me that the work in question would appear that week. I again thought I should hear from Professor Horsley at once, and, not hearing, towards the end of that week I wrote the statement of my results, which appeared in THe LANCET of Feb. 3rd. As to Professor Horsley's assertion that I had told him some time ago that I had abandoned the work I have no recollection of having made that statement. It is true that, as is clear in $\mathrm{my}$ original note, I had given it up at one time, a time when there was in my experience no sufficiently sure method of tracing the degeneration; but on the introduction of the more suitable method it was only natural that I should open investigation by aid of it. It is on no account to be inferred from the above that I admit for one moment that Professor Horsley has any exclusive right to this research. As for his claim to its initiation, it is true that some years ago he addressed to me a letter on the subject, for which, perhaps, he can remember I wrote and thanked him at the time; but the problem had already been the subject of experiment altogether prior to his writing to me on the point. Professor Horsley has brought into the issue between himself and me the name of Professor Boyce. I have myself in consequence been obliged in this letter to make use of Professor Boyce's name. I wish at once to assure him that I should have scrupulously avoided such reference had it been possible. I remain, Sirs, yours faithfully,

Feb. 13th, 1894

C. S. SHERRINGTON

\section{GENERAL PRACTICE, THE CLUB, AND THE HOSPITAL. \\ To the Editors of THE LANCET.}

SIRs, - We all know that hospitals are abused and in some cases very much abused, but the assumption that the general practitioner is the chief sufferer from this abuse does not seem to be altogether justified. In the case of special hospitals it is the medical staff who suffer by giving advice to people who are able to pay for it and who would pay for it if they found that the advice could only be obtained in that way. In the case of the special hospitals it is not a question between the hospital and the general practitioner, but merely whether the patient is to go to the hospital or to pay properly for the advice of the surgeon. Possibly the general practitioner has more to complain of in the case of the general $h$ spitals, but there is a set-off in regard to whatever loss he may sustain through hospitals of any kind in the fact that the vast majority of patients who attend hospitals at $e$ persons belonging to clubs. The hospitals, therefore, do a large part of the work which the general practitioner is paid for, and 